HENRYK SAMSONOWICZ

Instytut Historyczny

Uniwersytetu Warszawskiego

\title{
UWAGI DOTYCZĄCE 1050. ROCZNICY CHRZTU POLSKI
}

Tematyka związana z 1050. rocznicą chrztu Mieszka I, podjęta przez Redakcję „Kwartalnika Historycznego”, jest niewątpliwie okazją do poruszenia wielu zagadnień dotyczących nie tylko dziejów powstawania Państwa Polskiego, lecz także związanych z problematyką powszechną, jako że można i należy je rozpatrywać pod kątem wydarzeń tworzących mapę dzisiejszej Europy.

Chrzest Mieszka I mieści się bowiem na szerokim planie wydarzeń związanych z włączaniem wielu ziem i wielu wczesnych organizacji państwowych do chrześcijańskiej wspólnoty cywilizacyjnej. W X w. weszły do niej nowe, rozległe ziemie, obejmujące ponad milion kilometrów kwadratowych naszego kontynentu, leżące między Łabą i dorzeczem Wołgi oraz między Skandynawią i pobrzeżami Morza Czarnego. Zapewne już rychło po chrzcie, prawdopodobnie 2 stycznia 968 r., papież Jan XIII powołał do życia biskupstwo poznańskie. Co zaś wydaje się szczególnie ważne dla polskiego Kościoła, to fakt bezpośredniego podporządkowania nowej diecezji Stolicy Apostolskiej. Niezależnie od tego, czy stanowiło to świadectwo szczególnego znaczenia nowego biskupstwa, czy wiązało się z szerokimi planami papiestwa dotyczącymi chrystianizacji ziem leżących dotychczas poza wpływami Rzymu (podobnie jak założenie w tym samym czasie nieodległego biskupstwa miśnieńskiego), Poznań stał się ośrodkiem ziemi wcielonej do łacińskiej wspólnoty.

Ten sukces odniesiony w dziele chrystianizacji pogańskiej części Europy zasługuje na szczególną uwagę przynajmniej z dwóch powodów: po pierwsze stanowił wydarzenie znaczące $\mathrm{w}$ procesie przyjmowania nowej religii. Chrześcijaństwo było wyznacznikiem kultury wielu mieszkańców Europy, określającym nie tylko podstawowe normy etyczne obowiązujące człowieka, uznawane wartości, lecz także wprowadzającym wspólną 
rachubę czasu, podstawową wiedzę w zakresie chronologii świata oraz elementy uniwersalnego języka ułatwiającego kontakty gospodarcze, polityczne, z czasem także kulturalne. Przyjmowanie nowej religii stanowiło znaczący sukces w skali powszechnej: do wspólnoty cywilizacyjnej zostały przyjęte ludy żyjące poza dotychczasowym kręgiem kultury chrześcijańskiej. Drugi powód, dla którego wydarzenia zachodzące w X stuleciu zasługują na szczególną uwagę, to czas, w którym miało miejsce owo rozszerzenie się chrześcijaństwa. Trudno bowiem czas, w którym nastąpiła ekspansja nowej wiary, zaliczyć do korzystnych okresów w dziejach Kościołów na wschodzie i na zachodzie. Kryzysy i walki wewnętrzne między różnymi stronnictwami w Rzymie, kłopoty trapiące Konstantynopol zagrożony ekspansją arabską, słabości południowego pogranicza chrześcijańskiego na półwyspach Pirenejskim i Apenińskim - wszystkie te procesy dziejowe mogłyby wskazywać na narastające trudności przy promowaniu nowej wiary. W tym trudnym okresie do wspólnoty chrześcijańskiej zostały przyjęte rozległe ziemie Europy. W ciągu niezbyt długiego czasu przyjęli z Rzymu chrzest władcy trzech państw skandynawskich, Polska, Węgry, z Bizancjum - Ruś Kijowska, wzmocniła się organizacja Kościoła w Czechach.

Warto rozważać, czy było to spowodowane rosnącymi powiązaniami gospodarczymi między ziemiami Europy, czy może przenikaniem na pogańskie ziemie wschodu i północy wzorców państwowych z krajów ustrojowo i społecznie bardziej zaawansowanych. Być może to zjawisko było efektem dwóch czynników: konsolidacji wspólnot plemiennych, poszukujących nowych form organizacyjnych i ideologicznych, oraz coraz szerszej wymiany informacji o otaczającym świecie.

Jeśli pod pojęciem Europy rozumiemy obszar chrześcijański, to wydarzenia w krajach Europy Środkowej zachodzące w wieku X stanowiły z pewnością jeden z ważniejszych etapów jego kształtowania.

W dziejach Polski przyjęcie chrześcijaństwa zapoczątkowało jej istnienie wśród państw Europy. Nie tylko dlatego, że zaczęła być obecna w ówczesnych stosunkach dyplomatycznych, że zaczęły ukazywać się pierwsze wzmianki pisane o istnieniu państwa Mieszka, że włączona została do łacińskiej organizacji kościelnej, lecz także, że w szybkim czasie stała się podmiotem działań militarnych prowadzonych wobec sąsiednich krajów. Jej awans na polu międzypaństwowym w ciągu pierwszego półwiecza po przyjęciu chrztu może budzić zdziwienie. Powstanie gnieźnieńskiej metropolii, organizacja biskupstw (których granice ulegały w kolejnych latach rozmaitym zmianom), rozszerzanie granic władztwa piastowskiego w wyniku sukcesów odnoszonych w wojnach z sąsiadami, niekiedy już wcześniej tworzących formy państwowe, małżeństwa polskich dynastów z księżniczkami z różnych domów panujących - wszystkie te wydarzenia 
bardzo wyraźnie poświadczają szybki wzrost znaczenia państwa pierwszych Piastów. Wydaje się, że chrzest Mieszka I stanowił niewątpliwy bodziec przyśpieszający wzrost znaczenia jego władztwa.

Nie powtarzając wielu opinii dotyczących roli chrztu w 966 r. nie tylko dla Polski, lecz także dla całej Europy Środkowej, warto rozważyć niektóre pytania postawione przez Redakcję „Kwartalnika Historycznego". Na pewno do tych o pierwszorzędnym znaczeniu należy pytanie, co stanowi o chrześcijańskości kraju i społeczeństwa. Trudno przypuszczać, by zmieniły się szybko i w sposób zasadniczy normy etyczne i sposoby postępowania poddanych księcia polańskiego. Można raczej sądzić, że chrzest Mieszka był bardziej decyzją polityczną dotyczącą wejścia jego kraju do wspólnoty państw chrześcijańskich niż aktem wiary. O niezbyt zaangażowanej w krzewieniu nowej religii działalności księcia świadczy być może pośrednio fakt, że w przeciwieństwie do innych władców przyjmujących chrześcijaństwo - Włodzimierza na Rusi, Olafa w Norwegii, Eryka w Szwecji, Stefana na Węgrzech - Mieszko nie został wyniesiony na ołtarze. Czy zadecydowały o tym względy polityczne, słabe kontakty księcia polańskiego z Rzymem, niechęć książąt Rzeszy do konkurenta walczącego o dojście do drogi bałtyckiej trudno dać jednoznaczną odpowiedź na to pytanie. Mogło zadecydować o tym niezbyt rozległe położenie państwa polańskiego w połowie $\mathrm{X}$ w., ale nawet rosnące znaczenie Polski w czasach Bolesława Chrobrego nie zmieniło stosunku Stolicy Apostolskiej do Domu Piastowskiego. Jest to problem czekający na wyniki dalszych badań.

Nie ulega przy tym wątpliwości, że chrzest Mieszka I stanowił bardzo istotny, przełomowy moment $\mathrm{w}$ długim procesie przyjmowania chrześcijaństwa przez mieszkańców nadwarciańskich ziem. Zapewne nie dla wszystkich z nich było to pierwsze zetknięcie się z wyznawcami nowej wiary. Niektórzy poddani Mieszka musieli się bowiem stykać z chrześcijaństwem za pośrednictwem kupców z południa kontynentu, wędrujących już od paru stuleci do brzegów Bałtyku lub korzystających z lądowej drogi wzdłuż Wisły i dalej przez Wołyń na Ruś Kijowską. Niektórzy zapewne brali udział w wyprawach łupieżczych, docierających do krajów już dawniej schrystianizowanych.

Nie sposób zakładać, że chrzest władcy i jego otoczenia spowodował masowe przyjęcie chrześcijaństwa przez wszystkich jego poddanych. To wydarzenie, mimo znaczenia, jakie miało w dziejach Polski, nie było chyba przełomem w życiu wszystkich jej mieszkańców. Organizacja Kościoła dopiero powstawała, wysiłek inwestycyjny pierwszych władców przyniósł wprawdzie efekty w postaci kilku, może kilkunastu kościołów, ale trudno sądzić, by liczba duchownych prowadzących katechizację 
była wystarczająco duża wobec potrzeb kilkuset tysięcy mieszkańców kraju. Na pewno ograniczały działalność duchownych bariery językowe. Być może, tak jak miało to miejsce na Pomorzu półtora wieku później, zwoływane były wiece, liczące jednak chyba najwyżej kilkuset uczestników - by tam, po ogłoszeniu woli księcia, odprawić ceremonię chrztu. Dla większości mieszkańców ziem nadwarciańskich nowe reguły życia zapewne początkowo odbierane były bardziej w kategoriach różnych nakazów i zakazów niż w treściach religijnych.

Chrzest wiązał się z początkami zasadniczych przemian kulturowych zachodzących w życiu mieszkańców kraju, przemian, które trwać miały długie wieki po roku 966. Jeszcze bowiem w XV w. Jan Długosz utyskiwał na wciąż utrzymujące się pogańskie zwyczaje ludu polskiego, a niektóre ich cechy w życiu codziennym mogą być widoczne niemal do dnia dzisiejszego. Nie ulega jednak wątpliwości, że w życiu codziennym dokonywały się zmiany obyczajowe. Czasami stopniowo przyswajały one stare tradycje, stare kształty działań sakralnych do nowych reguł religijnych. Proces ten trwał długo, niekiedy, jak w przypadkach różnych obyczajów - przy żniwach, przy obrzędach weselnych, przy pogrzebach - funkcjonowały dawne gesty, przyśpiewki, zwyczaje aż do czasów niemal nam współczesnych.

Można zadać sobie pytanie, jak liczna była w wieku X populacja świadoma przyjmowania nowej wiary. Wydaje się, że początkowo składała się ona z otoczenia księcia, z przybyszów z chrześcijańskich krajów, ale nie można wykluczyć też grona, zapewne niezbyt licznych, miejscowych mieszkańców kraju wyznających chrześcijaństwo już wcześniej. Kontakty ludności mieszkającej nad Wartą i Wisłą z wyznawcami religii chrześcijańskiej miały przecież miejsce już od paru wieków. Wymiana handlowa z ziemiami Bizancjum, z Wielkimi Morawami, z Cesarstwem Zachodnim, umożliwiała, przynajmniej pobieżne, poznawanie obyczaju chrześcijańskiego. Przyjmowanie niektórych obyczajów - może rzadziej religijnych, ale zapewne towarzyszących transakcjom handlowym - przynoszonych z ziem już od dawna schrystianizowanych wydaje się nie budzić wątpliwości.

Adaptacja nowej wiary przyśpieszała wraz z nakładaniem świadczeń materialnych na rzecz tworzonej organizacji kościelnej. Czy w Polsce miały miejsce wydarzenia podobne do zachodzących na Rusi, gdzie książę Włodzimierz nakazywał demonstracyjnie niszczyć obiekty starego kultu? Nie mamy na ten temat wiadomości, biorąc jednak pod uwagę, że nowe kościoły stawiane były na miejscach dawniejszych obrzędów kultowych, być może jakieś działania zmierzające do niszczenia pomników pogańskich lub przystosowywania do potrzeb nowej religii mogły występować także w Polsce. Wydarzenia związane z tak zwaną reakcją pogańską w latach trzydziestych wieku XI zapewne świadczyły nie tyle o niechęci do 
wprowadzanych form życia poddanego obowiązkom religijnym, ile o próbach odrzucenia nakładanych świadczeń na potrzeby Kościoła.

W jakich dziedzinach wprowadzany był w życie poddanych Mieszka I obyczaj chrześcijański? Można sądzić - opierając się na późniejszych analogiach znanych z ziem chrystianizowanych i z nielicznych źródeł współczesnych - że mógł on dotyczyć przede wszystkim przestrzegania postów. Pierwotnie zapewne udział w nabożeństwach mieszkańców państwa Mieszkowego nie był zbyt masowy. Na przeszkodzie, poza oczywistym brakiem posiadanej wiedzy, stała zapewne mała liczba kościołów. Można co prawda przypuszczać, biorąc pod uwagę analogie z ziem Państwa Wielkomorawskiego, że w stołecznych grodach mogły być wznoszone przez możnych z otoczenia księcia niewielkie świątynie. Takie działania poświadczone są jednak dopiero dla XI w. Nie mamy materialnych świadectw, które by potwierdzały istnienie prywatnych fundacji, a łączna liczba znanych świątyń wzniesionych w X stuleciu nie była duża. Dopiero z czasem zaczęły powstawać ośrodki klasztorne i zapewne przynajmniej sto lat później kościoły wznoszone w prywatnych włościach możnowładczych.

Na pewno z biegiem lat język miejscowy był wzbogacany słowami modlitw i głoszonymi kazaniami. Dzięki katechizacji ludności przyśpieszał rozwój rodzimego słownictwa. Nauki prowadzone w kościołach musiały być prowadzone w języku zrozumiałym dla słuchaczy. Na pewno wykorzystywały zwroty z języka czeskiego, wprowadzały słowa wywodzące się z łaciny, greki, zapewne z niemieckiego. Używane terminy i formuły modlitewne były w miarę szybko przyswajane w modlitwach i pobożnych pieśniach, które rozpowszechniały się po kraju, ułatwiając zrozumienie przekazywanych treści mieszkańcom bliższych i dalszych okolic. Używany język na pewno był nieco odmienny w poszczególnych dzielnicach kraju (które to różnice pozostały niekiedy do dziś), ale zapewne w miarę szybko wykształcał się wspólny sposób porozumiewania członków elit państwowych, zrozumiały dla rządzących i - przynajmniej częściowo - dla rządzonych.

Nie ulega wątpliwości, że chrzest Mieszka ułatwił - i jemu, i jego otoczeniu - nawiązywanie kontaktów z władcami pobliskich krajów. Stwarzał okazję do podejmowania kontaktów, zawierania sojuszy, nierzadko wzmacnianych małżeństwami zawieranymi z córkami sąsiednich książąt. Przyjęcie nowej religii umożliwiało skuteczniejszą politykę zagraniczną, prowadzoną zrozumiałym językiem, zakładającą uznawanie - przynajmniej w teorii - wspólnych wartości.

Chrzest przeprowadzony w obrządku łacińskim definiował też kierunki zainteresowań polityki prowadzonej przez księcia polańskiego. Nie dotyczyły one, przynajmniej w pierwszym okresie dziejów jego państwa, 
kontaktów z Cesarstwem Wschodnim, z Rusią, z ziemiami leżącymi nad Morzem Czarnym, lecz kontaktów państwa Polan z Rzymem, z odradzającym się Cesarstwem Zachodnim i, jak się wydaje, z pobrzeżem Bałtyku.

Tradycja dworska i w Gnieźnie, i w Kijowie podkreślała rolę kobiet w dziele nawracania. Nie wchodząc w omawianie wędrownego wątku o przynoszeniu nowej wiary przez niewiasty, można podkreślić tu znaczenie chrześcijańskiego otoczenia władców, wskazując na ich małżonki. Zapewne już przed chrztem budowane były dla nich kaplice, sprowadzani byli kapłani. Ponoć Dobrawa, jak chciał Thietmar, „przybyła w wielkim przepychu kościelnej okazałości”. Niewątpliwie na decyzji księcia o przyjęciu chrztu zaważyły przede wszystkim plany dotyczące wzmocnienia jego władztwa. Nie można jednak pomijać znaczenia małżeństwa Mieszka z chrześcijańską księżniczką jako istotnego czynnika wpływającego na modernizację państwa.

Nie wiemy, jak było ono nazywane przez swych mieszkańców. Wiara w poszczególne bóstwa tworzyła jeden ze znaków rozpoznawczych wspólnoty, drugim było imię jej przywódcy, trzecim - nazwa wspólnoty plemiennej. Wydaje się, że w połowie wieku X władztwo Mieszka określane było jego imieniem. Przyjęcie chrześcijaństwa jednak włączało kraj Polan w szersze związki powstające w rozległej części Europy, jego nazwa - Polska - (czy rzeczywiście dopiero od roku 1000?) zaczynała funkcjonować na licznych dworach.

Od czasu chrztu można mówić o początku historii Polski jako wspólnoty ponadplemiennej. Oczywiście nie zawsze jednolitej językowo, obyczajowo, nie zawsze podlegającej wspólnemu władcy. $\mathrm{Na}$ osi chronologicznej wydarzeń zachodzących w dziejach naszego państwa dzień chrztu stanowi (i chyba zawsze stanowił) punkt zerowy, od którego liczy się przeszłość Polski i dzieje jej mieszkańców. 